\title{
Terrorism and the ECJ: Empowerment and democracy in the EC legal order
}

\author{
By
}

\section{Takis Tridimas}

Reprinted from European Law Review

Issue 1, 2009

Sweet \& Maxwell

100 Avenue Road

Swiss Cottage

London

NW3 3PF

(Law Publishers) 


\title{
Analysis and Reflections \\ Terrorism and the ECJ: Empowerment and democ- racy in the $\mathrm{EC}$ legal order
}

\author{
Takis Tridimas*
}

LT Competence; EC law; European Court of Justice; Fundamental rights; Sanctions; Terrorism; United Nations resolutions

In its judgment in Kadi \& Al Barakaat International Foundation v Council ( $C$ 402/05 P \& C-415/05 P) Not yet reported September 3, 2008, the ECJ held that the Community has competence to adopt economic sanctions not only against states but also against individuals on the basis of Arts 301, 60 and 308 EC. It also held that UN Security Council resolutions are binding only in international law and cannot take precedence over the Community's internal standards for the protection of fundamental rights. The judgment raises some profound constitutional questions pertaining to the competence of the Community, its relationship with international law and the scope of fundamental rights protection. In parallel, in a number of cases culminating in its judgment of October 23, 2008 in People's Mojahedin Organisation of Iran v Council (OMPI II) (T-256/07), the CFI has annulled anti-terrorist sanctions imposed by the European Community indicating a strong adherence to process rights. The purpose of this contribution is to discuss the above case law and its implications.

\section{Introduction}

In the European Union's flawed system of governance, democracy finds solace in judicial review. Perhaps no other case in the history of the European Union illustrates this better than the judgment of the ECJ in Kadi and Al Barakaat $v$ Council. ${ }^{1}$ The judgment is important for a number of reasons. First, it shows how the European Community relates to the world beyond its borders. It is in fact the most important judgment ever delivered by the ECJ on the relationship between Community and international law. Secondly, it makes important pronouncements of principle in relation to the competence of the Community and the scope of fundamental rights protection under Community law. In its judgment, the ECJ held that the Community has competence to adopt economic sanctions not only against states but also against individuals. It also held that UN Security Council (UNSC) resolutions are binding only in international law and cannot take precedence

\footnotetext{
* Sir John Lubbock Professor of Banking Law, Queen Mary College, University of London.

${ }^{1}$ Kadi \& Al Barakaat International Foundation v Council and Commission (C-402/05 P \& C-415/05 P) Not yet reported September 3, 2008.
} 
over the Community's internal standards for the protection of fundamental rights. On the basis of those findings, the ECJ reversed the judgment of the CFI under appeal ${ }^{2}$ and annulled the contested regulation which implemented a UNSC resolution.

In relation to competence and the reception of international law, the ECJ's approach is decidedly "sovereignist". In relation to fundamental rights protection, it is unmistakably liberal. The underlying values of the judgment are respect for liberal democracy and Community empowerment. These values are by no means unfamiliar to the ECJ but it has not expressed them so confidently since its seminal judgment in Internationale Handelsgesellschaft. ${ }^{3}$ The present author has attempted to analyse in detail the ECJ judgment in Kadi and the case law of the CFI on economic sanctions elsewhere. ${ }^{4}$ This note seeks to highlight selective aspects of the judgment in Kadi focusing in particular on three issues: Community competence, the reception of international law in the EU legal order, and the protection of fundamental rights. It also seeks to examine briefly the case law of the CFI on Community sanctions with particular reference to its judgment in OMPI II ${ }^{5}$ which was delivered after the ECJ's judgment in Kadi.

The origins of Kadi and Al Barakaat lie in counter-terrorism measures adopted by the UN Security Council (UNSC). Before the collapse of the Taliban regime, the Security Council adopted two resolutions ${ }^{6}$ requiring all Member States to freeze the funds and other financial resources owned or controlled by the Taliban and their associates. The Security Council also set up a Sanctions Committee which was responsible, inter alia, for drawing up a list of persons and entities whose funds would be frozen pursuant to the resolutions. ${ }^{7}$ Taking the view that action by the Community was necessary to implement these resolutions, the EU Council adopted two CFSP common positions ${ }^{8}$ which were, in turn, implemented by two Council Regulations ${ }^{9}$ adopted on the basis of Arts 60 and 301 EC.

After the collapse of the Taliban regime, the Security Council adopted two further resolutions ${ }^{10}$ which also provided for the freezing of funds but, this time, they were directed against Usama bin Laden, members of Al-Qaeda network, and the Taliban. Since they no longer controlled the government of Afghanistan, the resolutions in

${ }^{2}$ Kadi v Council and Commission (T-315/01) [2005] E.C.R. II-3649; Yusuf and Al Barakaat International Foundation v Council and Commission (T-306/01) [2005] E.C.R. II-3533; [2005] 3 C.M.L.R. 49.

${ }^{3}$ Internationale Handelsgesellschaft mbH $v$ Einfuhr- und Vorratsstelle fur Getreide und Futtermittel (11/70) [1970] E.C.R. 1125; [1972] C.M.L.R. 255.

${ }^{4}$ T. Tridimas and J.A. Gutierrez-Fons, "EU Law, International Law and Economic Sanctions against Terrorism: The Judiciary in Distress?" (2009) 32 Fordham International Law Journal 901.

${ }_{5}$ People's Mojahedin Orgnaisation of Iran v Council (OMPI II) (T-256/07) Not yet reported October 23, 2008.

${ }^{6}$ Security Council Resolution 1267(1999) of October 15, 1999, and Resolution 1333(2000) of December $19,2000$.

${ }^{7}$ The Sanctions Committee was established by Resolution 1267(1999).

${ }^{8}$ Common Position 1999/727/CFSP concerning restrictive measures against the Taliban [1999] OJ L294/1 and Common Position 2001/154/CFSP concerning additional restrictive measures against the Taliban and amending Common Position 96/746/CFSP [2001] OJ L057/1.

${ }^{9}$ Regulation 337/2000 concerning a flight ban and a freeze of funds and other financial resources in respect of the Taliban of Afghanistan [2000] OJ L43/1; Regulation 467/2001 prohibiting the export of certain goods and services to Afghanistan, strengthening the flight ban and extending the freeze of funds and other financial resources in respect of the Taliban of Afghanistan, and repealing Regulation 337/2000 [2001] OJ L67/1.

${ }^{10}$ Security Council Resolution 1390(2002) of January 28, 2002 and Security Council Resolution 1453(2002) of December 24, 2002. 
question targeted solely non-state actors. Those resolutions were also implemented at EU level. The Council adopted two new CFSP common positions ${ }^{11}$ which were implemented respectively by Regulations 881/2002/12 and 561/2003.13 This time, the Council relied as the legal basis for the adoption of the regulations not only on Arts 60 and 301 but also on Art.308 EC. The Sanctions Committee amended and supplemented the sanctions list a number of times and, each time, the amendments were introduced in Community law by respective amendments to the Community regulations.

In Kadi and Al Barakaat, the applicants were respectively a Saudi Arabian national and a Swedish national who had been included in the lists drawn by the UN Sanctions Committee and, consequently, in the lists incorporated in implementing Community regulations. They brought proceedings before the CFI seeking the annulment of those regulations alleging breach of their fundamental rights, namely, the right to a fair hearing, the right to respect property, and the right for effective judicial review.

\section{EC competence: the revolving door of Article $308 \mathrm{EC}$}

The first issue that the Community judiciary had to grapple with was competence: Does the Community have competence to adopt economic sanctions against individuals? Both the CFI and the ECJ found that the contested sanctions could be adopted on the combined legal basis of Arts 301, 60 and 308 but reached that result on the basis of different reasoning. A.G. Maduro opined that Arts 301 and 60 provided sufficient legal basis for the measure.

At first instance, the CFI held that, since the sanctions targeted individuals who were neither associated with the incumbent government nor had links with a particular territory, there was no sufficient link between the targeted individuals and a third country and, therefore, Arts 301 and $60 \mathrm{EC}$ could not by themselves empower the Community to impose sanctions. ${ }^{14}$

It considered, nevertheless, that Community competence could be established with the assistance of Art.308 as a joint legal basis. It pointed out that Arts 60 and $301 \mathrm{EC}$ are wholly special provisions in that they enable the Council to take action to achieve the objectives not of the Community but of the Union. Under Art.3 TEU, the Union is to be served by a single institutional framework and ensure the consistency of its external activities as a whole. Just as all the powers provided for by the EC Treaty may prove to be insufficient to allow the institutions to act in order to attain one of the objectives of the Community, so the powers to impose economic sanctions provided for by Arts 60 and $301 \mathrm{EC}$ may prove to be insufficient to allow the institutions to attain the objectives of the CFSP. There are therefore good grounds for accepting that, in the specific context contemplated by Arts 60 and $301 \mathrm{EC}$, recourse to the additional legal basis of Art.308 $\mathrm{EC}$ is justified for the sake of the requirement of consistency laid down in Art.3 TEU. ${ }^{15}$

\footnotetext{
${ }^{11}$ Common Position 2002/402/CFSP [2002] OJ L139/4; and Common Position 2003/140/CFSP [2003] OJ L53/62.

${ }^{12}$ Regulation 881/2002 imposing certain specific restrictive measures directed against certain persons and entities associated with Usama bin Laden, the Al-Qaida network and the Taliban [2002] OJ L139/9.

${ }^{13}$ Regulation 561/2003 amending, as regards exceptions to the freezing of funds and economic resources, Regulation 881/2002 [2003] OJ L82/1.

${ }^{14}$ CFI judgment in Kadi [2005] E.C.R. II-3649 at [93]-[97].

${ }^{15} \mathrm{Kadi}$ [2005] E.C.R. II-3649 at [127]-[128].
} 
On appeal, A.G. Maduro rejected the legitimacy of recourse to Art.308 but opined that Arts 60 and $301 \mathrm{EC}$ are by themselves sufficient legal bases. First, he employed a textual argument. He pointed out that the only requirement provided for in Arts 301 and 60 is that the Community measures adopted thereunder must interrupt or reduce economic relations with third countries. The Treaty does not regulate what shape the measures should take, who should be the target or who should bear their burden. ${ }^{16} \mathrm{He}$ reasoned that, by adopting sanctions against entities located in third countries, economic relations between the Community and these countries are also inevitably affected. ${ }^{17}$ Secondly, he argued that the CFI's restrictive reading of Art.301 deprived it of much of its practical use as it disabled the Community from adapting to modern, mutating threats to international peace and security.

The ECJ found the Advocate General's reasoning unconvincing. It held that the contested sanctions could not be adopted solely on the basis of Arts 60 and 301 EC since they did not bear any link to the governing regime of a third country. The essential purpose and object of the contested regulation was to combat international terrorism and not to affect economic relations between the Community and the third countries where the listed persons were located.18

The ECJ took the view that the contested sanctions could be adopted on the combined legal basis of Arts 60, 301 and $308 \mathrm{EC}$ but for reasons different from those accepted by the CFI. It found the bridge rationale of the CFI lacking. First, it held that, although Arts 60 and 301 establish a bridge between the imposition of economic sanctions by the Community and CFSP objectives, such bridge does not extend to other provisions of the Treaty. Action under Art.308 can only be undertaken in order to attain one of the objectives of the Community which cannot be regarded as including the objectives of the CFSP. ${ }^{19}$ Secondly, the Court took the view that recourse to Art.308 would run counter to the inter-pillar nature of the Union. The constitutional architecture of the pillars, as intended by the framers of the Treaties, militated against any extension of the bridge to articles of the EC Treaty other than those which explicitly created a link. ${ }^{20}$ Finally, employing the rationale of Opinion 2/94,21 it held that Art.308 EC, being an integral part of an institutional system based on the principle of enumerated competences, cannot serve as a basis for widening the scope of Community powers beyond the framework created by the Treaty provisions defining its tasks and activities. ${ }^{22}$

Despite the above, the ECJ found that Art.308 was correctly included in the legal basis of the contested regulation. It reasoned that, although Arts 60 and 301 authorised only sanctions against states, recourse to Art.308 could be made to extend their limited ambit ratione materiae, provided that the other conditions for its applicability were satisfied. ${ }^{23}$ Inasmuch as they provide for Community powers to impose economic sanctions in order to implement CFSP action, Arts 60 and 301 are the expression of an implicit

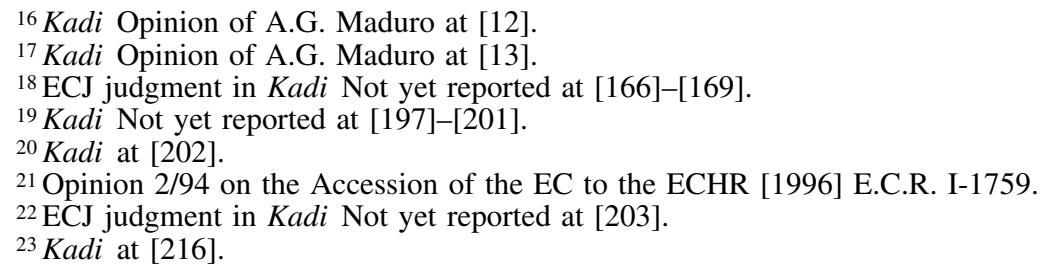


and underlying Community objective, namely that "of making it possible to adopt such measures through the efficient use of a Community instrument". ${ }^{24}$ This, the Court held, was a Community objective for the purposes of which the residual clause of Art.308 can be utilised. The Court also found that the second condition of Art.308, namely that the measure must relate to the operation of the common market, was also fulfilled so that it was possible to adopt the contested regulation on the basis of the combined basis of Arts 60, 301 and 308 EC.

The reasoning of the ECJ is problematic. The Court appears to draw a distinction between the ultimate objectives pursued by the underlying CFSP common position, which was to maintain international peace and security, and a separate, instrumental, objective of the contested regulation, namely to prevent certain persons associated with terrorism from having at their disposal economic resources. The distinction between objectives which coexist at separate levels allows Art.308 to be used as a revolving door. Whilst Art.308 could not be utilised to fulfil directly the first, it could be utilised to fulfil the second. The Community objective pursued, in fulfilment of which Art.308 could be resorted to, was not to combat terrorism but to make it possible to adopt the measures envisaged by Arts 60 and 301 "through the efficient use of a Community instrument". ${ }^{25}$ This distinction however appears to put the cart before the horses: If Arts 60 and 301 only authorise the imposition of sanctions against states, as the Court proclaimed that they do, how can it be said that their objectives include the imposition of sanctions against individuals? In effect, the Court's reasoning confuses means with objectives and is self-contradictory. The ECJ indirectly allows Art.308 to be elevated to an inter-pillar legal basis thereby undermining its earlier finding that Art.308 cannot be used to pursue CFSP objectives.

There is a second aspect of the Court's reasoning which appears unconvincing. The Court held that the second condition for the application of Art.308, namely that the measure must relate to the operation of the common market, was satisfied. It held that, if economic sanctions were imposed unilaterally by each Member State, the multiplication of national measures might affect the operation of the common market. Such measures could affect interstate trade, especially the movement of capital and payments and the right of establishment. In addition, they could create distortions of competition, since any differences between state sanctions could operate to the advantage or disadvantage of the competitive position of certain economic operators. ${ }^{26}$

This reasoning does not appear persuasive for the following reasons. The purpose of the sanctions is clearly not to regulate the common market but to combat terrorism. Any effects that they may have on free movement are incidental. In defining the scope of harmonisation action under Art.95 EC, the ECJ has held that there must be a need to eliminate substantial or "appreciable" distortions in competition. ${ }^{27}$ In the present case, there is scant evidence that such distortions might arise in the absence of Community legislation and, in any event, the Court did not attempt to engage in any inquiry to determine the threshold of appreciability. Similarly, under established case law, a mere

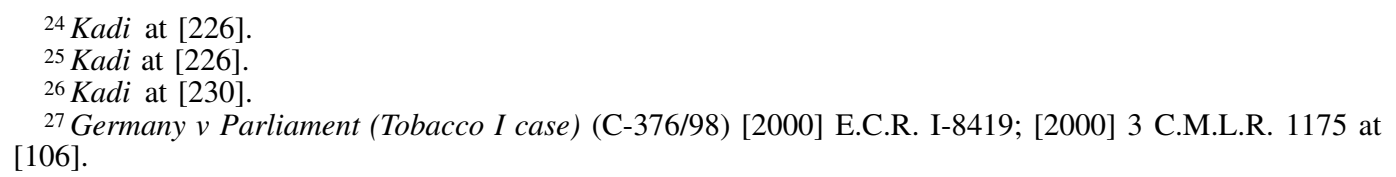


risk of disparities between national rules and a theoretical risk of obstacles to free movement or distortions of competition is not sufficient to justify the use of Art.95.28 Although recourse to Art.95 EC is possible if the aim is to prevent the emergence of future obstacles to trade resulting from multifarious development of national laws, the emergence of such obstacles must be likely and the measure in question must be designed to prevent them. ${ }^{29}$ It does not appear that the contested regulation in Kadi fulfils this test. As the CFI pointed out, the implementation of the UNSC resolutions by the Member States would not pose a serious danger of discrepancies in the application of sanctions. For one thing, the UNSC resolutions contained clear, precise and detailed definitions and obligations that left scarcely any room for interpretation. For another, the importance of the sanctions was so great that there was no reasonable danger of inconsistent application at the national level. ${ }^{30}$ Taken at face value, the ECJ's rationale in Kadi suggests that the threshold which triggers the application of Art.308, a residual provision, is much lower than the threshold which triggers Art.95, the main internal market tool of the Treaty.

The final argument used by the Court also raises objections. The Court held that adding Art.308 to the legal basis of the contested regulation enables the European Parliament to take part in the decision-making process whereas Arts 60 and 301 provide for no such role for the Parliament. This argument echoes of Titanium Dioxide ${ }^{31}$ and recognises the democratic deficit in the imposition of sanctions. It is however not capable of triggering the application of Art.308 or any other legal basis where its substantive conditions are not fulfilled. ${ }^{32}$

Despite the above criticisms, one can understand why, from a policy perspective, it appears preferable to take counter-terrorist action at Union rather than at Member State level. The making of counter-terrorist policy, its implementation via binding legal measures, and its actual enforcement stand a much higher chance of being successful if they are coordinated at supra-national level. Terrorist financing, in particular, transcends national frontiers and can be combated much more effectively by coordinated action rather than by isolated measures taken by individual States. At a micro-level, EU action enhances the Union's credentials as a powerful actor in foreign and security policy. It also serves the interests of Member States in a number of ways. It provides an efficient law-making mechanism for the adoption of anti-terrorism measures. It also neutralises awkward questions or objections that might be aired under national decision-making processes, offering the opportunity for shifting the blame to the European Union. In short, taking action at Union level is more efficient, politically expedient, and, most importantly, stands a higher chance to be effective. The European Union can thus be seen as the natural home for counter-terrorist decision making.

${ }^{28}$ Germany v Parliament (Tobacco II case) (C-380/03) [2007] 2 C.M.L.R. 1 at [37]; R. (on the application of Alliance for Natural Health) v Secretary of State for Health (Vitamins case) (C-154/04 \& C-155/04) [2005] E.C.R. I-6451; [2005] 2 C.M.L.R. 61 at [28].

${ }^{29}$ See, e.g. Tobacco II [2007] 2 C.M.L.R. 1 at [39], [41]; Netherlands v Parliament (C-377/98) [2001]

E.C.R. I-7079; [2001] 3 C.M.L.R. 49 at [15]; Vitamins case [2005] E.C.R. I-6451 at [29].

${ }^{30}$ See CFI judgment in Kadi [2005] E.C.R. II-3649 at [113].

${ }_{31}$ Commission v Council (Titanium Dioxide) (C-300/89) [1991] E.C.R. I-2867; [1993] 3 C.M.L.R. 359.

${ }^{32}$ cf. Commission v Council (Waste Disposal Directive Case) (C-155/91) [1993] E.C.R. I-939 where the ECJ distinguished Titanium Dioxide [1991] E.C.R. I-2867 and placed limits on the argument of democracy. The positioning of this argument in the body of the judgment in Kadi [2005] E.C.R. II-3649 also appears somewhat odd. It is included at [235] as a last, subordinate, argument added almost as an afterthought. 
From the legal point of view, as the Treaties stand at the moment, ${ }^{33}$ the issue of Community competence is highly problematic and Kadi can justly be seen as a borderline case. In view of the language of Art.301, establishing Community competence requires a leap of faith. If such a leap is to be performed at all, it can be performed more persuasively by relying solely on Arts 60 and 301 rather than invoking Art.308. There are four arguments in favour of Community competence: First, as the Advocate General opined, the language of Art.301 does not exclude the imposition of sanctions against individuals. Secondly, a historical interpretation of the provision suggests that the authors of the Treaty had no intention to exclude such sanctions. Thirdly, a teleological and evolutionary interpretation favours competence to impose sanctions against non-state actors. Finally, such interpretation appears suited to the nature of Art.301 as a pasarelle provision which provides a bridge between the first and the second pillar.

As the CFI accepted, Art.301 was designed to enable the Community to comply with international commitments of the Member States, especially those undertaken under the auspices of the UN. ${ }^{34}$ It is correct, as the ECJ pointed out, that an exact correlation between Art.41 of the UN Charter which authorises the Security Council to adopt economic sanctions and Art.301 cannot be drawn. The fact, however, that Art.301 refers only to the imposition of economic sanctions on third countries does not mean that the authors of the Treaty purposefully excluded sanctions against non-state organisations. At the time when that provision was introduced by the TEU, smart sanctions simply did not exist as instruments of foreign policy. 35

If applied consistently, a narrow interpretation of Art.301 EC would appear to lead to odd practical results. It would be possible for the Community to impose sanctions on non-state entities who finance a rogue regime or a rebel group which exercises de facto control over part of the territory of a country but, as soon as the rogue regime falls or the rebel group is defeated, the Community would no longer be able to renew the sanctions even if the targets continued to pose a substantial and imminent threat to the political stability of the country in question. This would hardly by compatible with the need to maintain international peace and stability which is one of the key objectives of the CFSP and the underlying aim of Art.301 EC. ${ }^{36}$ In short, a narrow interpretation

\footnotetext{
${ }^{33}$ The discussion about competence would be otiose if the Lisbon Treaty came into force. Article 215(2) on the Functioning of the European Union (TFEU) expressly grants the Council power to adopt restrictive measures against individuals, groups and non-state groups on the basis of a CFSP decision. Such measures can be challenged by way of direct action: see Art.24(1) TEU, as amended by the Lisbon Treaty, and Art.275(2) TFEU.

${ }^{34}$ See CFI judgment in Kadi [2005] E.C.R. II-3649 at [202].

35 Article 41 TEU authorises the UNSC to take measures which "may include complete or partial interruption of economic relations". Article 301, by contrast, refers to "action by the Community to interrupt or to reduce in part or completely economic relations with one or more third countries" (emphasis added). This difference in terminology however is by no means conclusive. Prior to the introduction of Art.301 by the TEU, economic sanctions against third countries were imposed on the basis of Art.133 EC on the common commercial policy. That provision was designed to serve trade policy objectives and its use for the adoption of sanctions pursuing foreign policy objectives was controversial. With the insertion of Art.301 EC, the drafters of the TEU sought to avoid discrepancies between CFSP objectives and the implementing powers of the Community. Article 301 did not refer to non-state actors since at the time of its introduction smart sanctions were not used as an instrument of foreign policy. See G. Zagel, Sanctions of the European Community: A Commentary on Art.301 TEC. Law of the European Union, available at http://ssrn.com/abstract $=862024$ [Accessed December 10, 2008] and P. Koutrakos, EU International Relations Law (Hart, 2006), pp.423-424.

${ }^{36} \mathrm{~A}$ further argument in support of the view that Arts 301 and $60 \mathrm{EC}$ are sufficient legal basis is that these provisions refer to "third countries", as opposed to "third states". The term "countries" is wider than
} 
of Art.301 would be based on a formalistic distinction between state and private action which would not do justice to the forces that shape the sources and exercise of political power.

Finally, from the humanitarian point of view, and also from the point of view of adverse legal repercussions, it would be odd if it was accepted that Arts 301 and 60 EC enable the Community to do more, i.e. impose comprehensive sanctions against countries which burden the whole of the population, but not less, i.e. adopt targeted sanctions against specific groups. It may be retorted that this is the language of political expediency rather than the language of law. Still, insofar as the purpose of Art.301 as a pasarelle is to provide means to achieve objectives, the rationale of smart sanctions adds credence to a purposive and evolutive interpretation of that provision.

Thus, if it is to be accepted that the Community has competence, it is submitted that the appropriate basis should be found in Arts 310 and 60 and that recourse to Art.308 EC is superfluous. As A.G. Maduro noted, Art.308 cannot serve as an inter-pillar bridge. It is strictly an enabling provision which provides the means but not the objective. ${ }^{37}$ Either a measure targeting non-state actors comes within the objectives of the CFSP, in which case it can be adopted under Art.301 EC, or it does not, in which case Art.308 cannot be used as its basis. Increasing the quantity of legal bases cannot improve their quality.

\section{The effect of UNSC resolutions in the Community legal order}

Once it was established that the Community had competence to adopt the contested sanctions, the next issue to consider was the effect of UNSC resolutions in the Community legal order. On this issue, the CFI and the ECJ took diametrically opposing views. The CFI adopted an internationalist approach. It accepted that whilst the Community is not bound by the UN Charter by virtue of international law, it is so bound by virtue of the EC Treaty itself. ${ }^{38}$ It based such primacy on the combined effects of Arts 307(1) and 297 EC and the theory of substitution. ${ }^{39}$ Article 307(1), which was central to the CFI's reasoning, seeks to preserve the binding effect of international agreements concluded by Member States before they assumed obligations under the EC Treaties. The CFI pointed out that, at the time when they concluded the EC Treaty, the Member States were bound by their obligations under the UN Charter. Referring to International Fruit, ${ }^{40}$ it held that, by concluding the EC Treaty between them, the Member States could not transfer to the Community more powers than they possessed or withdraw from their obligations to third countries under the UN. ${ }^{41}$ It followed that the Community was under an obligation to respect Member States' obligations under the Charter. The CFI found that the binding effect of the Charter barred it from reviewing the validity of the contested regulation

\footnotetext{
"states" and appears to encompass the population rather than solely the government or the concept of public power in the sense of etat.

${ }^{37}$ Kadi [2005] E.C.R. II-3649 at [15] of the Opinion.

${ }^{38}$ CFI judgment in Kadi [2005] E.C.R. II-3649 at [192], [203]-[204].

39 This theory posits that, where under the EC Treaties the Community assumes powers previously exercised by the Member States in an area governed by an international agreement, the provisions of that agreement become binding on the Community. It was developed by the ECJ in International Fruit Co NV $v$ Produktschap voor Groenten en Fruit (No.3) (21-24/72) [1972] E.C.R. 1219; [1975] 2 C.M.L.R. 1.

40 International Fruit [1972] E.C.R. 1219.

${ }^{41}$ CFI judgment in Kadi [2005] E.C.R. II-3649 at [188].
} 
on the basis of Community law. Since the regulation implemented a UNSC resolution, review of the former would inevitably carry with it incidental review of the latter, which would be incompatible with the primacy of the Charter. The CFI accepted however that UNSC resolutions must observe the fundamental peremptory provisions of jus cogens and proceeded to examine whether the contested sanctions complied with them. By this construct, the CFI sought to reach a golden balance. It affirmed the primacy of the UN Charter over Community law whilst subjecting the Security Council to principles endogenous to the legal system at the apex of which it stands. This reasoning however is neither logically inevitable nor constitutionally secure.

The ECJ was less concerned with the primacy of the UN Charter and more preoccupied with reiterating the autonomy and constitutional credentials of Community law. Invoking Les Verts, ${ }^{42}$ it held that the Community is based on the rule of law and that neither its Member States nor its institutions can avoid review of the conformity of their acts with the EC Treaty as the Community's basic constitutional charter. It then stated that an international agreement cannot affect the allocation of powers fixed by the Treaties or the autonomy of the Community legal system. ${ }^{43}$ It emphasised that fundamental rights form an integral part of the general principles of Community law and that compliance with them is a sine qua non for the lawfulness of Community action. ${ }^{44}$ On that basis, it concluded that the obligations imposed by an international agreement cannot have the effect of prejudicing the constitutional principles of the EC Treaty. ${ }^{45}$ The ECJ's approach is firmly a sovereignist one. Asserting the "constitutional hegemony" 46 of EC law, it did not allow the primacy of the UN Charter to perforate the constitutional space of the Community legal order making a clear-cut distinction between the international obligations of the Community and the effect of Community norms, no matter their source, within the Community legal order.

The ECJ's approach is preferable. In contrast to the argumentation of the CFI, neither Art.307 nor Art.297 EC appear capable of dislodging the jurisdiction of the Community courts to apply fundamental rights. Articles 307(1) and 297 are exceptional provisions of the Treaty which, under certain conditions, authorise Member States to depart from Community rules to serve international law commitments. But they do not impose on the Community an obligation to suspend the application of fundamental constitutional principles. It is simply not convincing to argue that all tasks that the Member States, or the Community in their lieu, are called upon to take at any time in the future as a result of UNSC resolutions are simpliciter exempted from the fundamental guarantees of Community law. As A.G. Maduro stated, Art.307 may not grant UNSC resolutions with a "supra-constitutional" status and render Community measures implementing UN

\footnotetext{
42 Parti Ecologiste Les Verts v Parliament (294/83) [1986] E.C.R. 1339; [1987] 2 C.M.L.R. 343 at [23]. ${ }^{43}$ ECJ judgment in Kadi Not yet reported at [282] referring to Opinion 1/91 [1991] E.C.R. I-6079 at [35] and [71], and Commission v Ireland (C-459/03) [2006] E.C.R. I-4635; [2006] 2 C.M.L.R. 59 at [123].

${ }^{44}$ Kadi Not yet reported at [283]-[284] and see further Opinion 2/94 at [34], and Eugen Schmidberger Internationale Transporte Planzuge v Austria (C-112/00) [2003] E.C.R. I-5659; [2003] 2 C.M.L.R. 34 at [73].

${ }^{45} \mathrm{Kadi}$ at [285].

${ }^{46}$ The expression is borrowed from P.J. Spiro, "Treaties, International Law, and Constitutional Rights" (2000) 55 Stanford Law Review 1999.
} 
law immune from judicial review. ${ }^{47}$ In the light of Art.6(1) TEU, under no circumstance may the Community depart from its founding principles, in particular, respect for human rights and fundamental freedoms. The case law of the ECJ also demonstrates its serious commitment to the rule of law under which measures in breach of human rights are excluded from the Community legal order. Thus, neither Art.297 nor Art.307 may permit any derogations from the principles laid down in Art.6(1) TEU which form part of the very foundations of the Community legal order.48

Notably, the ECJ distinguished the situation in Kadi from Behrami and Saramati. ${ }^{49}$ In that case, the ECtHR had dismissed the complaint of the applicants that their Convention rights had been violated by action undertaken during the Kosovo conflict. The action had been undertaken by French, German and Norwegian nationals in the service of UNMIK and KFOR. ${ }^{50}$ The ECtHR found that the actions of the defendant states were directly attributable to the UN which by a Security Council resolution had delegated its powers to establish international security and civil presences to UNMIK and KFOR. In a deferential judgment, the ECtHR attributed particular significance on the imperative nature of maintaining peace and security as the principal aim of the UN and the powers accorded to the UNSC under Ch.VII to fulfil that aim. In doing so, it appeared to concede that the aim of maintaining peace and security and the uniqueness of the UN takes priority or, at least, conditions heavily the aims of the ECHR. In Kadi, the ECJ dismissed the relevance of Behrami on two grounds. First, it held that the legal and factual setting of the case was fundamentally different and, secondly, it asserted the ideological autonomy of the Community legal order. The Convention is designed to operate primarily as an interstate agreement which creates obligations between the Contracting Parties at the international level and provides only minimum protection..$^{51}$ The EC Treaty, by contrast, has founded an autonomous legal order, within which states as well as individuals have immediate rights and obligations and on the basis of which the ECJ ensures respect for fundamental rights as a "constitutional guarantee". ${ }^{52}$

There is no denying that there are important differences between Behrami and Kadi. Whilst the former involved actions directly attributable to the UN, in the latter the Member States acted as sovereign actors giving effect to UNSC resolutions..$^{53}$ The ECtHR accepted as much in Behrami, by distinguishing the case from Bosphorus. ${ }^{54}$ Furthermore,

${ }^{47}$ ECJ judgment in Kadi Not yet reported at [304] of the ECJ's judgment and see, per A.G. Maduro at [25] of his Opinion.

${ }^{48}$ Kadi Not yet reported at [303]-[304].

${ }^{49}$ Behrami v France (2007) 45 E.H.R.R. SE10. For other cases where the Strasbourg Court examines the relationship between the Convention and the UN Charter or international more generally, see, e.g. Al-Adsani $v$ United Kingdom (2002) 34 E.H.R.R. 11; Banković v Belgium and 16 Other Contracting States (2007) 44 E.H.R.R. SE 5.

${ }^{50}$ UNMIK was the United Nations Interim Administration Mission in Kosovo and KFOR was the security force established in Kosovo by UNSC Resolution 1244(1999).

51 The Charter of Fundamental Rights of the European Union expressly views the Convention as providing a minimum threshold: see Art.52.3.

${ }^{52}$ See Kadi Not yet reported at [316]-[317] of the ECJ judgment and at [21] and [37] of the Opinion of A.G. Maduro.

53 There are also obvious differences between Kadi Not yet reported and $R$. (on the application of Al Jedda) $v$ Secretary of State for Defence [2007] UKHL 58. Although in the latter the House of Lords accepted that the actions of the British troops were attributable to the UK and not to the UN, the factual setting and the legislative framework of the case were fundamentally different.

${ }^{54}$ Bosphorus Hava Yolları Turizm ve Ticaret Anonim Şirketi v Ireland (2006) 42 E.H.R.R. 1. 
the distinct feature of Kadi is that the UN resolutions in issue were in fact not general but concrete and individual in nature, akin to national administrative acts, since they specified the persons to whom they applied. This made the availability of judicial review all the more imperative.

\section{The protection of fundamental rights}

The different starting points of the CFI and the ECJ determined respectively the intensity of their fundamental rights inquiry. Since, under its reasoning, the primacy of the UN Charter prevented review of the contested regulation on the basis of EC standards, the CFI proceeded to assess whether the regulation complied with the principles of jus cogens and came to the conclusion that it did. The ECJ, by contrast, subjected the sanctions to unforgiving, full review on the basis of EC standards.

The CFI appears to adopt a distinct notion of jus cogens. Article 53 of the 1969 Vienna Convention on the Law of the Treaties defines jus cogens as peremptory norms of general international law which are accepted and recognized by the international community of states as a whole as norms from which no derogation is permitted. In fact, the concept of "jus cogens" is far from clear. Although it is accepted that human rights fall within its scope, disagreement persists as to the precise rights which may be included thereunder. In Kadi, the applicant alleged that the contested regulation had breached the right to a fair hearing, the right to property and the right to an effective judicial review. Although these rights have long been recognised as fundamental in the Community legal order, it is by no means obvious that they can be considered as jus cogens. In Kadi, the CFI followed a broad understanding of jus cogens, encompassing under it all the rights pleaded by the applicants. In its reasoning, the function of jus cogens was not to exclude rights which would otherwise be applicable but to lower substantially the degree of judicial scrutiny by pushing well back the threshold of review.

The CFI found that none of the rights pleaded by the applicants had been violated. In relation to the right to property, it pointed out that the measure pursued an objective of fundamental public interest for the international community. Freezing of funds was a temporary precautionary measure which did not affect the right to property as such but only the use of financial assets. The CFI placed particular emphasis on the fact that the applicable rules provided a derogation from the freezing of funds necessary to cover basic expenses (e.g. foodstuffs, rent, and medicines) and thus, any degrading or inhuman treatment was avoided. 55

In relation to the right to be heard, the CFI drew a distinction between the right to a hearing before the Council and before the Sanctions Committee. Before the former, it held that such a right was not applicable since the Council did not enjoy any discretion in implementing UNSC resolutions. ${ }^{56}$ As regards the procedure before the Sanctions Committee, the CFI did acknowledge that any opportunity for the applicant to present his views on the evidence adduced against him was excluded. Nonetheless, the CFI

${ }^{55}$ CFI judgment in Kadi [2005] E.C.R. II-3649 at [241].

${ }^{56}$ Kadi [2005] E.C.R. II-3649 at [257]-[258]. 
took the view that this was an acceptable restriction given that what was at stake was a temporary precautionary measure restricting the availability of the applicant's property. 57

Finally, in relation to the right of judicial review, the CFI acknowledged that there was no judicial remedy available to the applicant since the Security Council had not established an independent international court responsible for ruling in actions brought against decisions of the Sanctions Committee. It accepted however that the resulting lacuna was not in itself contrary to jus cogens. ${ }^{58}$

The CFI saw the judicialisation of diplomatic protection as a way of compensating for the lack of sufficient remedies and turned to national courts to fill the gap of judicial protection left by its deference to the UNSC. It pointed out that it is open to the persons concerned to bring an action for judicial review based on domestic law against any wrongful refusal by the national authorities to submit their case to the Sanctions Committee for reconsideration. ${ }^{59}$ Subsequently, in Ayadi ${ }^{60}$ and Hassan, ${ }^{61}$ which were decided before the ECJ's judgment in Kadi, the CFI raised the standard by holding that the UNSC resolutions did not render inapplicable obligations stemming from general principles of EU law, pursuant to which the Member States must,

"ensure, so far as possible, that the interested persons are put in a position to put their point of view before the competent national authorities where they present a request for their case to be reviewed". ${ }^{2}$

Thus, rediscovering the spirit of Jégo-Quéré, ${ }^{63}$ the CFI required Member States to provide for judicial review of a refusal by national authorities to take action with a view to guaranteeing the diplomatic protection of their nationals. ${ }^{64}$ It held that prompt state action before the Sanctions Committee is required, unless the state concerned puts forward sufficient reasons justifying its refusal to act, which are then submitted to the scrutiny of the judiciary. This "judicialisation" of diplomatic protection, however, falls well short of the requirements of the right to judicial protection as understood in Community law proper. The CFI's reasoning is, in effect, unconvincing because it creates a huge crater in the right to judicial protection.

In contrast to the judgment of the CFI, the ECJ's approach displays constitutional confidence and distrust towards any invasion on due process. Recalling the spirit of Les Verts, ${ }^{65}$ the Court began by stating that effective judicial protection is a general principle of Community law which emanates from the constitutional traditions common to the Member States and has been enshrined in Arts 6 and 13 of the ECHR. It also referred by way of supporting argument to Art.47 of the EU Charter of Fundamental

${ }^{57}$ Kadi at [273]-[274].

${ }^{58}$ Kadi at [287]-[290].

${ }^{59} \mathrm{Kadi}$ at [270].

${ }^{60}$ Ayadi v Council (T-253/02) [2006] E.C.R. II-2139.

${ }^{61}$ Hassan v Council (T-49/04) [2006] E.C.R. II-52.

${ }^{62}$ Ayadi [2006] E.C.R. II-2139 at [147]; Hassan [2006] E.C.R. II-52 at [117].

${ }^{63}$ Commission v Jégo-Quéré et Cie SA (C-263/02 P) [2004] E.C.R. I-3425; [2004] 2 C.M.L.R. 12. In that case the ECJ called upon Member States to fill the gap left by its restrictive interpretation of the conditions that must be fulfilled under Art.230(4) EC in order for individuals to have locus standi to seek judicial review of Community acts directly before the Community courts.

${ }^{64}$ Ayadi [2006] E.C.R. II-2139 at [152]; Hassan [2006] E.C.R. II-52 at [121].

${ }^{65}$ Les Verts [1986] E.C.R. 1339. 
Rights, thus continuing a recent tendency to view its provisions as a legitimate source of inspiration. 66

The Court held that the principle of judicial protection requires that the Community authorities must communicate to the persons concerned the grounds on which their names have been included in the sanctions list. The requirement to notify reasons serves both an instrumental and a rule of law-based rationale. It enables those affected to defend their rights and also facilitates the exercise of judicial review by the Court. ${ }^{67}$ It agreed with the CFI that, in the circumstances of the case, advance communication to the appellants of the reasons for their inclusion in the sanctions lists or granting them in advance the right to be heard would prejudice the effectiveness of the sanctions. A freezing of assets order can only be effective if it has an element of surprise and no advance warning is given. The Court also accepted that overriding public policy considerations may militate against the communication of certain matters to the persons concerned and, therefore, against their being heard. ${ }^{68}$ The ECJ thus impliedly recognised the need for protecting information derived from intelligence sources.

This did not mean, however, that the contested sanctions would be immune from judicial review. This point was developed further by A.G. Maduro, who rejected the argument that the fight against terrorism is a "political question" unfit for judicial determination. Whilst conceding that the ECJ operates in an increasingly interdependent world where the authority of other international bodies must be recognised, the Advocate General highlighted that the Community judiciary cannot "turn its back on the fundamental values" 69 which it is bound to protect. Measures intended to suppress international terrorism cannot enjoy judicial immunity, the reason being that,

"the political process is liable to become overly responsive to immediate popular concerns, leading the authorities to allay the anxieties of the many at the expense of the rights of a few".70

This was echoed by the Court which found that it was the judiciary's task to apply,

"techniques which accommodate, on the one hand, legitimate security concerns about the nature and sources of information taken into account in the adoption of the act concerned and, on the other, the need to accord the individual a sufficient measure of procedural justice". ${ }^{71}$

${ }^{66}$ ECJ judgment in Kadi Not yet reported at [335]; Charter of Fundamental Rights of the European Union, proclaimed on December 7, 2000 in Nice [2000] OJ C364/1. The ECJ broke its silence and referred to the Charter for the first time in Parliament v Council (C-540/03) [2006] E.C.R. I-5769; [2006] 3 C.M.L.R. 28 at [38]. For subsequent references, see, e.g. Unibet (London) Ltd v Justitiekanslern (C-432/05) [2007] E.C.R. I2271; [2007] 2 C.M.L.R. 30 at [37]; Advocaten voor de Wereld VZW v Leden van de Ministerraad (C-303/05) [2007] 3 C.M.L.R. 1 at [46]; Laval un Partneri Ltd v Svenska Byggnadsarbetareförbundet (C-341/05) [2008] 2 C.M.L.R. 9 at [91].

${ }^{67}$ Kadi Not yet reported at [336]-[337]. This dual rationale has been reiterated in previous case law: See Union Nationale des Entraineurs et Cadres Techniques Professionnels du Football (UNECTEF) v Heylens (222/86) [1987] E.C.R. 4097; [1989] 1 C.M.L.R. 901 at [15]; Dansk Rorindustri v Commission (C-189/02 P, C-202/02 P, C-205/02 P to C-208/02 P and C-213/02 P) [2005] E.C.R. I-5425; [2005] 5 C.M.L.R. 17 at [462] and [463].

${ }^{68}$ Kadi Not yet reported [342].

${ }^{69}$ Opinion of A.G. Maduro in Kadi at [44].

${ }^{70}$ Opinion of A.G. Maduro in Kadi at [45].

${ }^{71}$ ECJ judgment in Kadi at [344] 
Accordingly, the balance lay in mandating the Council to communicate inculpatory evidence against the appellants either concomitantly with the adoption of the contested regulation or within a reasonable period thereafter. Owing to the Council's failure to do so, the ECJ ruled that the applicants' right of defence, particularly their right to be heard, had been violated. Further, since the Court was deprived of investigating the evidence supporting the freezing of assets, it could not exercise review and, as a result, the right to effective judicial protection had also been breached. The Court identified the source of violation as being both the statutory framework and the Council's practice. Neither the contested regulation nor the CFSP Common Position which formed its basis provided for a procedure for the notification of evidence; furthermore, at no time did the Council inform the appellants of such evidence.

A distinct feature of the ECJ's reasoning, which differentiates its approach from that of the CFI, is that it conceded little ground to the source of the security concerns, namely the fact that the sanctions originated from the UNSC. It accepted that the Community must respect international law and, in that context, attach "special importance" to UNSC resolutions ${ }^{72}$ but this did not translate to granting any special status to Community measures adopted to comply with such resolutions when reviewing their compatibility with fundamental rights. Similarly, the ECJ accepted that it must balance "legitimate security concerns" 73 and heed to, "overriding considerations to do with safety or the conduct of the international relations of the Community and its Member States" 74 but by doing so, it emphasised the nature of the interests at stake rather than the UNSC as their ultimate exponent. The judgment is euro-centric rather than internationalist.

In relation to the right to property, the Court recalled that it is not an absolute right and its exercise may be restricted subject to two conditions. Such restrictions must: (a) pursue a public interest objective; and (b) meet the standard of proportionality, i.e. they must not constitute a disproportionate and intolerable interference impairing the very substance of the right. ${ }^{75}$ The ECJ found that, in principle, such justification existed. Drawing on the case law of the ECtHR, it acknowledged that the Community legislature enjoys a "great margin of appreciation" in choosing the means to attain public interest objectives and ascertaining their adequacy. ${ }^{76}$ Referring to its judgment in Bosphorus, ${ }^{77}$ the ECJ stressed the importance of adopting effective measures to combat terrorism in order to maintain international peace and security and accepted that such an imperative objective may justify even substantial collateral effects on bona fide third parties. Accordingly, freezing of assets as a means of counter-terrorism could not be qualified as a disproportionate restriction on the right to property. The Court took into account that, under the UN Sanctions scheme and the Community legislation giving effect to it, the freezing of funds to cover certain basic expenses could be lifted upon request of the affected parties. Furthermore, the UNSC resolutions provided for a mechanism of periodic re-examination

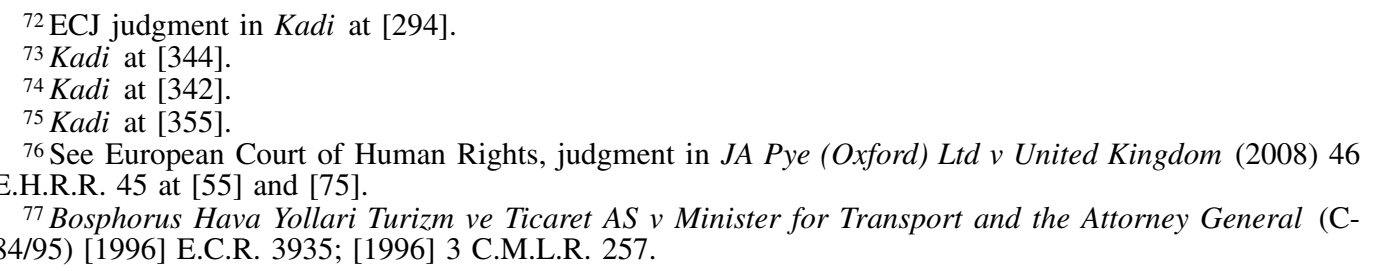


of the sanctions imposed and a procedure whereby affected parties could raise their claims.

Nevertheless, the ECJ found that, as applied to Mr Kadi, the contested regulation breached the right to property because it violated due process standards which are an integral part of that right. ${ }^{78}$ In so far as it concerned Mr Kadi, the contested regulation was adopted without furnishing any guarantee enabling him to put his case to the competent authorities and therefore constituted an unjustified encroachment upon his right to property.

\section{Process rights and Community sanctions}

Process rights have been examined in more detail by the CFI in the context of anti-terrorist sanctions provided by the Community and not prescribed by the UN. It is interesting to examine here the judgment of the CFI in People's Mojahedin Orgnaisation of Iran (OMPI) v Council (OMPI II Case), ${ }^{79}$ which was delivered after the ECJ's judgment in Kadi. Before examining the judgment of the CFI, it is necessary to explain briefly its background.

The legislative setting in OMPI II was different in that the contested sanctions list was not adopted at UN level but by the Community institutions acting in implementation of UNSC resolutions drafted in more general terms. In particular, CFSP Common Position 2001/931, 80 adopted to give effect to UNSC Resolution 1373(2001), mandated the European Community to order the freezing of funds and other economic resources of persons, groups and entities listed in the Annex. The key provision of the Common Position is Art.1(4) which states that the list in the Annex is to be drawn up on the basis of precise information which indicates that a decision has been taken by a competent authority in respect of the persons concerned, irrespective of whether it relates to the instigation of investigations or prosecution for a terrorist act, or an attempt to perpetrate, participate or facilitate such an act. The decision must be based on serious and credible evidence or clues, or condemnation for such deeds. "Competent authority" is understood to mean a judicial authority or, where judicial authorities have no competence in the relevant area, an equivalent authority. According to Art.1(6), the names of persons and entities in the list in the Annex are to be reviewed at regular intervals and at least once every six months to ensure that there are grounds for keeping them in the list.

Common Position 2001/931 was transposed into Community law by Regulation 2580/2001. ${ }^{81}$ Article 2 of that Regulation provided for the freezing of assets of the persons, groups and entities included in a sanctions list which is to be determined by a Council Decision. It also mandated the Council, acting by unanimity, to establish, review and amend that list in accordance with the provisions laid down in Common Position 2001/931. Since the initial sanctions list which was introduced in December

${ }^{78}$ See, to that effect, the judgment of the European Court of Human Rights in Jokela $v$ Finland (2003) 37 E.H.R.R. 26 at [45] and case law cited, and at [55].

79 People's Mojahedin Orgnaisation of Iran v Council (OMPI II) (T-256/07) Not yet reported October 23, 2008.

${ }^{80}$ CFSP Common Position 2001/931 [2001] OJ L344/93.

${ }^{81}$ Regulation 2580/2001 to counteract the financing of terrorist groups [2001] OJ L344/70. 
$2001,{ }^{82}$ the Council has adopted various common positions and decisions updating the lists respectively provided by the Common Position 2001/931 and Regulation 2580/2001.

In a number of cases, organisations or individuals who had been included in those lists brought proceedings before the CFI seeking their annulment. The basic findings made by the CFI may be summarised by reference to the judgment in Organisation des Modjahedines du people d'Iran (OMPI) v Council (OMPI I case),83 which was delivered before the ECJ's judgment in Kadi. The CFI held that the Community standards for the protection of fundamental rights applied in relation to the contested measures. It distinguished the case from Kadi on the ground that, in Kadi, the Community institutions had merely implemented resolutions of the UNSC and decisions of its Sanctions Committee which did not authorise the Community to provide for any mechanism for the examination of individual situations. In OMPI I, by contrast, although UNSC Resolution 1373(2001) provided that all states must freeze terrorist assets, it did not specify individually the persons and entities who were to be subject to the sanctions. Thus, the Community acts which specifically applied the sanctions did not come within the exercise of Community circumscribed powers and were not covered by the principle of primacy of UN law under Art.103 of the UN Charter. ${ }^{84}$ They were therefore subject to review on the basis of fundamental rights standards as they apply in Community law.

The CFI then proceeded to examine the requirements of the right to a hearing, the duty to give reasons and the right to judicial protection and found that they were breached. The applicant had not been notified of the evidence against it before proceedings commenced. Neither the initial decision to freeze its assets nor the subsequent decisions maintaining the freezing mentioned the specific information or material in the file, as required by Art.1(4) of Common Position 2001/931 showing that a decision justifying its inclusion in the disputed list had been taken by a national competent authority. Similarly, the $\mathrm{CFI}$ found that the requirement to state reasons had been violated. It placed particular emphasis on the fact that the complete lack of statement of reasons prevented it from exercising its function of judicial review. A distinct feature of the case was that, at the hearing, the Council and the United Kingdom were not able to explain to the Court on the basis of which national decision the contested decision had been adopted. The CFI therefore was not in a position to review the lawfulness of the contested decision. Furthermore, it stressed that the possibility of communicating the reasons after the application to the Court has been filed cannot not fulfil the requirements of the right to a hearing. ${ }^{85}$ The statement of reasons must appear in the contested decision or be provided "immediately thereafter", 86 and must be "actual and specific". 87

\footnotetext{
${ }^{82}$ Decision 2001/927 establishing the list provided for in Art.2(3) of Regulation 2580/2001 [2001] OJ L344/83.

83 Organisation des Modjahedines du people d'Iran (OMPI) v Council (T-228/02) [2006] E.C.R. II-4665; [2007] 1 C.M.L.R. 34. See also KONGRA-GEL (T-253/04) Not yet reported April 3, 2008; Osman Ocalan on behalf of PKK v Council (T-229/02) Not yet reported April 3, 2008; Stichting Al-Aqsa v Council (T-327/03) Not yet reported July 11, 2007; Sison v Council (T-47/03) [2007] 3 C.M.L.R. 39.

${ }^{84}$ OMPI I [2006] E.C.R. II-4665 at [99]-[102].

${ }^{85}$ See OMPI I [2006] E.C.R. II-4665 at [139]; KONGRA-GEL Not yet reported at [99]-[101].

${ }^{86}$ KONGRA-GEL Not yet reported at [102].

${ }^{87}$ Al Asqa Not yet reported at [61].
} 
The detailed examination of OMPI I and the other judgments of the CFI is beyond the scope of this article. ${ }^{88}$ Suffice it to make the following observations.

In OMPI I, the CFI had the opportunity to examine the requirements imposed by the right to a hearing in a mixed procedure, i.e. one involving both national and Community authorities. It pointed out that, under Art.1(4) of Common Position 2001/931, the procedure leading to a decision to freeze assets is taken at two levels, one national and the other Community. In the first stage, a competent national authority must take a decision that the party concerned is associated with terrorist acts. That decision must be based on serious and credible evidence or clues. In the second stage, the Council acting unanimously must decide to include the party concerned in the list on the basis of precise information which indicates that such a national decision has been taken.

The CFI held that the right to a fair hearing must be safeguarded primarily in the first stage, i.e. before the national authorities. It is at that stage that the party concerned must be placed in a position in which he can effectively present his views on the evidence, subject to possible restrictions on the right to a fair hearing which are justified in national law on grounds of public policy, public security or the maintenance of international relations.

By contrast, the right to a hearing has a relatively limited scope in the second phase of the procedure, which unravels at Community level. The party concerned must be afforded the opportunity to make his views known only on whether there is specific information in the file which shows that a decision meeting the definition laid down in Art.4(1) of Common Position 2001/931 was taken at national level. Observance of the right to a fair hearing does not in principle require that the party concerned be afforded again at that stage the opportunity to express his views on the appropriateness and well-foundedness of that decision, as those questions may only be raised at national level. Likewise, in principle, it is not for the Council to decide whether the proceedings opened against the party concerned and resulting in that decision, as provided for by the national law of the relevant Member State, were conducted correctly, or whether the fundamental rights of the party concerned were respected by the national authorities. That power belongs exclusively to the competent national courts under the oversight of the European Court of Human Rights. ${ }^{89}$

The CFI based this limitation of its review function on the principle of sincere cooperation provided in Art.10 EC which underpins the whole EU legal order. It held that Art.1(4) of Common Position 2001/931 and Art.2(3) of Regulation 2580/2001 introduce a specific form of co-operation between the Council and the Member States in the context of combating terrorism. In that context, the principle of sincere co-operation entails, for the Council, the obligation to defer as far as possible to the assessment conducted by the competent national authority, at least where it is a judicial authority, both in respect of the issue of whether there are "serious and credible evidence or clues" on which its decision is based and in respect of recognising potential restrictions on access to the

\footnotetext{
${ }^{88}$ For an analysis, see Tridimas and Gutierrez, "EU Law, International Law and Economic Sanctions against Terrorism: The Judiciary in Distress?" (2009) 32 Fordham International Law Journal 901. Note that in KONGRA-GEL, PKK Not yet reported and Al-Aqsa Not yet reported the CFI also annulled the contested sanctions but based its judgment solely on breach of the right to reasoning.

${ }^{89}$ OMPI I [2006] E.C.R. II-4665 at [121].
} 
evidence on grounds of public policy, public security or the maintenance of international relations.

The CFI, however, provided for an exception from this deferential approach. It held that the above considerations are valid only in so far as the evidence or clues in question were in fact assessed by the competent national authority. If, in the course of the procedure before it, the Council bases its initial decision or a subsequent decision to freeze funds on information or evidence communicated to it by representatives of the Member States without it having been assessed by the competent national authority, that information must be considered as newly-adduced evidence which must, in principle, be the subject of notification and a hearing at Community level, not having already been so at national level. ${ }^{90}$ This exception is based on the understanding that the Council is not bound by the EU Common Position, i.e. it does not have to include in the list all the persons included in the Common Position. ${ }^{11}$ It follows that, in deciding whether to include a particular person or entity in the list, the Council exercises discretion and may take account of information not placed before the national competent authority. In such a case therefore it must afford to the person concerned the right to express his views thus closing the remedial gap left by the lack of intervention of the national authority.

Despite the purposeful reiteration of the application of the right to a hearing as a matter of principle, the CFI recognised that it is subject to comprehensive limitations in the interests of the overriding requirement of public security. These limitations concern the timing of notification of the evidence, the type of evidence that may be notified, and the opportunity to present views on the evidence. In short, they permeate all its aspects.

Understandably, the CFI held that notifying the evidence and granting a hearing before the adoption of the decision to freeze funds would be liable to jeopardise the effectiveness of the sanctions and thus incompatible with the public interest objective of preventing terrorism: An initial measure freezing funds must, by its very nature, be able to benefit from a surprise effect and to be applied with immediate effect. Such a measure cannot, therefore, be the subject matter of notification before it is implemented. ${ }^{92}$ However, the evidence must be notified to the party concerned, in so far as is reasonably possible, either concomitantly with or as soon as possible after the adoption of the initial decision to freeze funds. ${ }^{93}$ The CFI also accepted that, although in principle the parties concerned must have the opportunity to request an immediate re-examination of the initial measure freezing their funds, such a hearing after the event is not automatically required in the context of an initial decision to freeze funds. The requirements of the rule of law are safeguarded by their right to seek judicial review before the CFI.94

${ }^{90}$ OMPI I [2006] E.C.R. II-4665 at [126].

91 The CFI also held that, when the Community implemented the EU Common Position, it did not act under powers circumscribed by the will of the Union or that of its Member States. It derived this from the wording of Art.301 EC, according to which the Council is to decide on the matter "by a qualified majority on a proposal from the Commission", and that of Art.60(1) EC, according to which the Council "may take", following the same procedure, the urgent measures necessary for an act under the CFSP.

${ }^{92}$ See OMPI I [2006] E.C.R. II-4665 at [128]; this was endorsed by the ECJ in Kadi Not yet reported, at [340]-[341]

${ }^{93}$ OMPI I [2006] E.C.R. II-4665 at [129].

${ }^{94}$ OMPI I at [130]. The above limitations do not apply to subsequent Council decisions maintaining the freezing of funds. Once assets have been frozen, it is no longer necessary to ensure a surprise effect to 
With regard to the evidence to be notified, the CFI recognised that overriding security concerns or considerations relating to the conduct of the international relations of the Community and its Member States may preclude the communication of certain evidence to the parties concerned and, therefore the hearing of those parties with regard to such evidence. ${ }^{95}$ The CFI took the view that such restrictions are consistent with the constitutional traditions of the Member States and the case law of the ECtHR. ${ }^{96}$

The CFI then proceeded to indicate the type of evidence whose communication may be restricted in the circumstances of the case. It held that the restrictions apply primarily to the "serious and credible evidence or clues" on which the national decision to instigate an investigation or prosecution is based but they may conceivably also apply to the specific content or the particular grounds for that decision, or even the identity of the authority that took it. It is even possible that, in very specific circumstances, the identification of the Member State or third country in which a competent authority has taken a decision in respect of a person may be liable to jeopardise public security, by providing the party concerned with sensitive information which it could misuse. ${ }^{97}$

It follows from the above that, in view of public security concerns, the right to a hearing is reduced in practice to a right to be notified of the evidence concomitantly, or as soon as possible thereafter, of the adoption of the economic sanction. The right to be heard after that is not "automatically" recognised. Given such severe limitations on the right to be heard, the requirement to state reasons becomes the central aspect of due process. The CFI accepted, however, that the requirement to give reasons is subject mutatis mutandis to the same limitations on overriding grounds as those applicable to the right to a hearing. Considerations concerning the security of the Community and its Member States, or the conduct of their international relations, may preclude disclosure to the parties concerned of the specific and complete reasons for the initial or subsequent decision to freeze their funds. Thus, the Council may be precluded from, first, disclosing the serious and credible evidence or clues on which the national decision to instigate an investigation or prosecution is based; secondly, even from referring in detail to the specific content or the particular grounds of that decision, and thirdly; "in very specific circumstances", from disclosing the identity of the Member State or third country in which a competent authority has taken the decision in question. ${ }^{98}$

In relation to the right to judicial protection, the CFI pointed out that judicial review is all the more imperative being the only procedural safeguard ensuring that a fair balance is struck between the need to combat international terrorism and the protection of fundamental rights. 99 The Community Courts must thus be able to review the lawfulness

guarantee the effectiveness of the sanctions so that any subsequent decision maintaining the sanction must be preceded by the possibility of a further hearing and, where appropriate, notification of any new evidence. This obligation applies irrespective of whether the persons concerned expressly made a prior request to be heard: $O M P I I$ at [131]-[132].

${ }^{95} \mathrm{OMPI} I$ at [133].

${ }^{96}$ See, e.g. Chahal $v$ United Kingdom (1997) 23 E.H.R.R. 413 at [131], and Jasper v United Kingdom (2000) 30 E.H.R.R. 441 at [51]-[53]; see also Art.IX.3 of the Guidelines adopted by the Committee of Ministers of the Council of Europe.

${ }^{97}$ Chahal v United Kingdom (1997) 23 E.H.R.R. 413 at [136].

${ }^{98}$ See OMPI [2006] E.C.R. II-4665 at [148] and [136].

${ }^{99}$ OMPI [2006] E.C.R. II-4665 at [155]. 
and merits of the measures to freeze funds without it being possible to raise objections that the evidence and information used by the Council is secret or confidential. The CFI thus put at rest the view that the executive may withhold evidence from the court or that they may oust the jurisdiction of a judicial body by invoking public security prerogative. ${ }^{100}$ It left open however the question whether the confidential information may be provided only to the CFI or be made available also to the lawyers of the applicant. ${ }^{101}$

The CFI acknowledged limitations on its power of review. First, it accepted that the Council enjoys broad discretion in adopting economic sanctions in implementation of CFSP policies. Secondly, it conceded that the Community Courts may not substitute their assessment of the evidence, facts and circumstances justifying the adoption of such measures for that of the Council. Thirdly, it held that the review carried out by the Court of the lawfulness of decisions to freeze funds must be restricted to checking that the rules governing procedure and the statement of reasons have been complied with, that the facts are materially accurate, and that there has been no manifest error of assessment of the facts or misuse of power. That limited review applies, especially, to the Council's assessment of whether the imposition of penalties was appropriate in the circumstances and the factors that it took into account in this context.102

\section{The level of judicial scrutiny and post-Kadi case law}

After the judgment in OMPI I, the Council informed OMPI that it intended to maintain its inclusion in the sanctions list. It provided OMPI with a statement of reasons and also informed it that it could submit observations within a period of one month. In its statement of reasons, the Council pointed out that a decision had been taken with respect to OMPI by a competent authority within the meaning of Art.1(4) of Common Position. That decision was an order by which the Home Secretary of the United Kingdom had proscribed the applicant as an organisation concerned in terrorism under the Terrorism Act 2000 .

Subsequently, and in accordance with the statement of reasons notified to OMPI, the Council adopted Decision 2007/445103 by which it provided for a new sanctions list and in which OMPI's name was maintained. OMPI sought the annulment of Decision $2007 / 445$ but, after the commencement of the proceedings, the Council adopted a new decision (Decision 2007/868) ${ }^{104}$ which repealed Decision 2007/445 and provided for a new sanctions list in which, again, the applicant's name appeared. After the adoption of Decision 2007/445 but before Decision 2007/868 there had been a material development: The Proscribed Organisations Appeal Commission (POAC) had allowed an appeal against

\footnotetext{
${ }^{100}$ This view finds support in the case law of the ECtHR. See, e.g. Chahal v United Kingdom (1997) 23 E.H.R.R. 413 at [135]; Öcalan $v$ Turkey (2003) 37 E.H.R.R. 10 at [106].

${ }^{101}$ See, in this context, Chahal v United Kingdom (1997) 23 E.H.R.R. 413 at [131] and [144]; Tinnelly \& Sons $v$ United Kingdom (1999) 27 E.H.R.R. 249 at [49], [51], [52] and [78]; Jasper v United Kingdom (2000) 30 E.H.R.R. 441 at [51] to [53]; and Al-Nashif v Bulgaria (2003) 36 E.H.R.R. 37 at [95] to [97], and also Art.IX.4 of the Guidelines adopted by the Committee of Ministers of the Council of Europe.

${ }_{102}$ OMPI [2006] E.C.R. II-4665 at [159] and, to that effect, Leander v Sweden (1987) 9 E.H.R.R. 433

Eur Comm HR at [59], and Al-Nashif v Bulgaria (2003) 36 E.H.R.R. 37 at [123] and [124].

${ }^{103}$ Decision 2007/445 [2007] OJ L169/58.

${ }^{104}$ Decision 2007/868 [2007] OJ L340/100.
} 
the Home Secretary's decision refusing to lift the proscription of the applicant and ordered the Home Secretary to lay before the Parliament the draft of an Order removing the applicant from the list of organisations proscribed under the Terrorism Act 2000. Decision 2007/868 was notified to the applicant by letter in which the Council took the view that the reasons for continuing to include the applicant in the list, as previously communicated, still held good. With regard to the POAC's decision, the Council observed that the Home Secretary had sought to bring an appeal against it.

The CFI found that whilst the Council had observed the applicant's process rights in adopting Decision 2007/445, it had failed to do so in adopting Decision 2007/868.

In relation to Decision 2007/445, the CFI held that the annulment of the contested decision in OMPI I did not prohibit the Council from adopting a new decision maintaining the freezing of its assets on the basis of the same decision of the national competent authority on which the original Council decision which was annulled in OMPI $I$ had been adopted. The CFI reiterated that, where a Community act is annulled on procedural grounds, the institution which authored the act may adopt a new measure which is identical in substance provided that it observes the formal and procedural rules whose breach gave rise to annulment and that the legitimate expectations of the persons concerned are duly protected. In the instance case, OMPI's legitimate expectations had been duly honoured because the Council had informed it of its intention to maintain its name in the list. 105

The CFI found that process requirements had been satisfied and that the Council had committed no manifest error of assessment. It had sent to the applicant a statement clearly and unambiguously explaining the reasons which, in its opinion, justified the applicant's continued inclusion in the list. In its statement, the Council had not merely relied on the Home Secretary's Order but also provided specific examples of acts of terrorism. Furthermore, it had acted on the basis of the Home Secretary's Order which was a decision of a national competent authority within the meaning of Art.1(4) of Common Position 2001/931. Under the duty of sincere cooperation, the Council was not required to question the assessment of the incriminating material by the national competent authority. Indeed, as the CFI noted, the Council was required to leave as much as possible to the assessment of that authority, in particular regarding the existence of the "serious and credible evidence or clues" on which the latter's decision was based. Whilst the Home Secretary was not a judicial authority, the fact that its decision was open to judicial review and that such an action was either not brought or did not lead to a decision in the applicant's favour, placed the Council in the same position. With regard to the weighing up of the incriminating and exculpatory evidence, the CFI took the view that the Council had acted reasonably. Where the decision of the national authority is the subject of challenge before the domestic courts, the Council should refuse in principle to express an opinion on the validity of the arguments on substance raised before the outcome of the proceedings is known. Otherwise, its assessment, as a political institution, would run the risk of conflicting with the assessment made by the domestic court.

By contrast, the CFI found that Decision 2007/868 was vitiated by illegality. The key point in the CFI's reasoning is that, where the Council decides to continue to include

${ }^{105}$ OMPI II Not yet reported at [75]-[76]. 
a person in the sanctions list, it is under an obligation to verify that a competent national authority must have taken a decision meeting the definition of Art.1(4) of Common Position 2001/931. Such verification is an "imperative" requirement. 106 Prior to the adoption of Decision 2007/868, the POAC had held that the decision of the Secretary of State refusing to declassify the applicant as a terrorist organisation was irrational. According to the POAC's assessment, the evidence proved that OMPI had ceased all terrorist activities since 2001 and disarmed in 2003. The CFI attached particular importance to the POAC's decision and also to the fact that the POAC had refused the Home Secretary permission to appeal to the Court of Appeal.

The CFI however did not annul Decision 2007/868 on substantive grounds. It held that, in view of the POAC's decision, the statement of reasons supporting Decision 2007/868 was insufficient. The Council's reasoning was in fact identical to the statement of reasons supporting the earlier Decision 2007/445. It did not therefore explain the actual and specific reasons why the Council took the view that, despite the decision of the POAC, OMPI should continue to be included in the sanctions list.

In OMPI II, the CFI clarified a number of points pertaining to the scope and content of process rights.

It reiterated that the Council must provide "actual and specific" reasons justifying the inclusion of a person in the list.107 Thus, the statement of reasons must refer not only to the legal conditions of application of Regulation 2580/2001, namely, the existence of a national decision taken by a competent authority, but also the reasons why the Council considers, in the exercise of its discretion, that the person concerned must be made the subject of a measure freezing funds. ${ }^{108}$ The obligation to provide reasons applies both to an initial decision to freeze funds and subsequent decisions maintaining a person's name in the list. However, when the grounds of a subsequent decision to freeze funds are in essence the same as those already relied on when a previous decision was adopted, a mere statement to that effect may suffice, particularly when the person concerned is a group or entity. 109

The right to a hearing does not necessarily entitle a person to a formal hearing where the legislation governing the matter in issue does not so provide. It suffices that the persons concerned have been put into a position where they can make their views effectively known to the authorities. ${ }^{110}$

There is no right to continuous conversation. The right to a hearing and the duty to state reasons do not necessarily require the decision-maker to answer specifically all the points raised by the person concerned. ${ }^{111}$

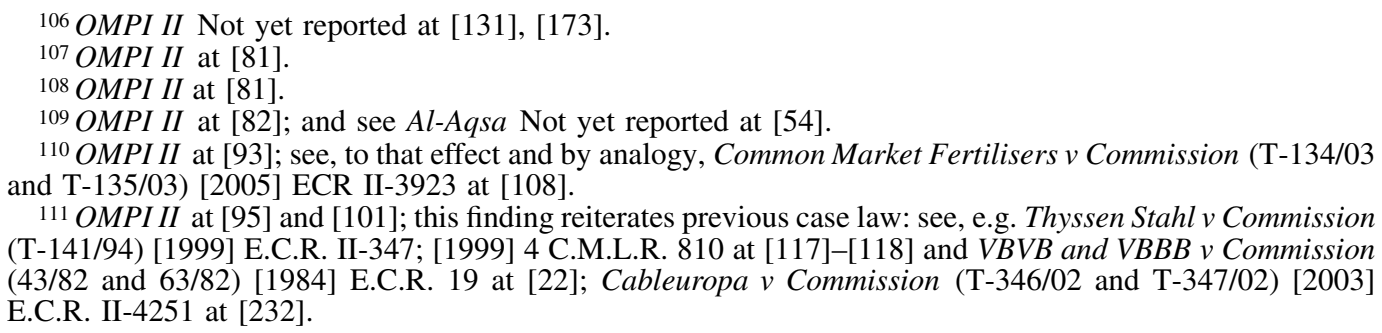

${ }^{111}$ OMPI II at [95] and [101]; this finding reiterates previous case law: see, e.g. Thyssen Stahl v Commission (T-141/94) [1999] E.C.R. II-347; [1999] 4 C.M.L.R. 810 at [117]-[118] and VBVB and VBBB v Commission (43/82 and 63/82) [1984] E.C.R. 19 at [22]; Cableuropa $v$ Commission (T-346/02 and T-347/02) [2003] E.C.R. II-4251 at [232]. 
Finally, the CFI rejected the argument that only present and current terrorist activity justifies inclusion in the list and that a person may not be included therein solely on the basis of past conduct. If that were accepted, the objectives of the Community sanctions regime and the UNSC Resolution 1373(2001) on which it was based would be undermined. The imposition of sanctions, being intended essentially to prevent the perpetration of terrorist acts or their repetition, is based more on the appraisal of a present or future threat than on the evaluation of past conduct. ${ }^{112}$

One of the most interesting aspects of OMPI II is the pronouncements of the CFI as regards the scope and the standard of judicial scrutiny in reviewing sanctions decisions. The starting point of the CFI is that the Council has broad discretion as to what to take into consideration for the purpose of adopting economic sanctions. This discretion concerns, in particular, the assessment of suitability of sanctions. The prime consideration in deciding whether to freeze someone's assets must be the Council's perception or evaluation of the danger that, if sanctions were not adopted, the funds in questions might be used to fund or prepare acts of terrorism. Subject to this criterion, the Council enjoys discretion in assessing the reasons why economic sanctions must be imposed on a specific person.

Although the Council enjoys broad discretion, this does not mean that the role of the judiciary is subdued. In determining the scope of the judicial inquiry, the CFI held that the Community judicature has in effect a threefold role. First, it must examine whether the requirements of the applicable law are fulfilled. Secondly, it must assess the evidence. In particular, it must establish whether the evidence relied on by the Council is factually accurate, reliable and consistent; whether it contains all the relevant information to be taken into account in order to assess the situation; and whether it is capable of substantiating the conclusions drawn from it. However, when conducting such a review, the Court must not substitute its own assessment of what is appropriate for that of the Council. ${ }^{113}$ Thirdly, it must review the observance of certain procedural guarantees which are of fundamental importance when the decision-maker enjoys wide discretion. In particular, it must review observance of the obligation of the competent institution to examine carefully and impartially all the relevant elements of the individual case and to give an adequate statement of the reasons for its decision. ${ }^{114}$

Despite the rhetoric used in the judgment, the standard of review favoured by the CFI appears to be only cautiously deferential and more intrusive than the manifest error test when used in reviewing legislative choices or broad economic, social or security policy. The reason for this is that the sanctions measures are individual rather than legislative in nature.

\section{Conclusion}

The judgment of the ECJ is Kadi is of major constitutional importance. On the one hand, it empowers the Community to play a role in foreign relations and security policy. On the other hand, it places fundamental rights at the apex of the Community edifice. In

${ }^{112}$ OMPI II at [109]-[110].

${ }_{113}$ OMPI II at [138].

${ }^{114}$ OMPI II at [139]. Such a review (at [141]) corresponds, in essence, to the review of a manifest error of assessment. 
fact, competence and fundamental rights protection are closely intertwined and the first predetermines the second: either the Community has competence to impose sanctions on individuals, in which case Community human rights standards apply, or the matter is to be left entirely to the Member States to deal with. In that respect, the judgment of the CFI leaves something to be desired. By opting for competence without protection, it reinforced a model of supra-national government which begs legitimacy.

The approach of the ECJ may be contrasted with that of the CFI in many respects. First, whilst the ECJ displays the confidence of a constitutional court and makes general pronouncements of principle, the CFI opts for a minimalist approach and avoids engagement with wider issues of human rights protection. Secondly, whilst the ECJ asserts the "constitutional hegemony" 115 of the EC and endorses a model of the Community as a self-contained legal order showing mistrust for outside sources of authority, the CFI prominently looks for allies in international and national law. In the CFI's reasoning, the primacy of the UN Charter makes the limits on its jurisdiction inevitable whilst the assistance of national legal systems is crucial to bridge the remedial gap left by Community law.

The issue of competence remains problematic. The judgment aptly illustrates that, given the integration potential of the EC Treaty, the division of powers between the Community and the Member States remains inherently unstable. As in many previous occasions, the ECJ errs on the side of Community competence on the basis of an instrumental rationale which, in terms of formal reasoning, remains somewhat unconvincing.

On the issue of fundamental rights protection, the ECJ's commitment is to be applauded. Inevitably, the Community judiciary will be drawn into finding a balance between, on the one hand, the overriding interests of public security and, on the other hand, the rights of the individual. In this respect, the judgment marks the beginning rather than the end of the inquiry. No doubt, the ECJ and the CFI will have the opportunity to pronounce and elaborate further on the limits of process rights and the appropriate level of judicial scrutiny. This is an extremely delicate task given the interests at stake. The judgments of the CFI in relation to Community sanctions suggest that, whilst it will not enter into questions of substance, it is prepared to make full use of process rights. The Community courts endorse different visions as to the relationship between international law and Community law but appear to stand much closer together in their understanding of what Community standards of fundamental rights require. The judgments serve to remind us that the other branches of government cannot take the judiciary for granted. As Lord Hailsham wisely observed: "Unlike the keepers of the seraglio, they [the judges] do not have their political or social opinions carefully removed." 116

\footnotetext{
115 See above fn. 46 .

${ }^{116}$ See Lord Hailsham, A True Conservative Lord Chancellor (1979) quoted by R. Stevens, "A loss of innocence? Judicial independence and the separation of powers" (1999) 19 Oxford Journal of Legal Studies 365,380 .
} 